\title{
ANALISIS MAKNA SIMBOLIS TRADISI SEDEKAH BUMI (NYADRAN) DAN PENDIDIKAN ISLAM DI KAPLONGAN LOR, INDRAMAYU
}

\author{
Fuadul Umam \\ Prodi Sejarah Kebudayaah Islam, Fakultas Islam Nusantara, Universitas Nahdlatul \\ Ulama Indonesia (UNUSIA) \\ E-mail: $\underline{\text { fuad @unusia.ac.id }}$
}

Article Information

Informasi Artikel

Naskah diterima: 28 January 2020

Naskah direvisi: 5 Maret 2020

Naskah disetujui: 10 Maret 2020

Naskah dipublish: 15 Oktober 2020

Keywords Culture,

Nyndaran Tradition, Islamic

Education

Kata Kunci Budaya, Tradisi Nyadaran, Pendidikan Islam

\begin{abstract}
Abstrak
The cultural reality of Indonesia, which is diverse in ethnicity, different traditions, as well as religions and traditions that smell of myths is the basis of social and cultural life. The Indonesian nation has long believed in supernatural powers that rule this universe. This is proven by various historical records regarding various kinds of traditional ceremonies and rituals. Some of these supernatural powers are considered beneficial and detrimental. For this reason, it is believed by some that humans always need to strive to soften the hearts of the owners of magical powers by holding ritual ceremonies, pilgrimages, offerings, and vows, including certain artistic performances. The tradition of earth alms (nyadran) in Kaplongan Lor, Karangampel, Indramayu is one of the local wisdoms that combines Hindu-Buddhist and Islamic traditions. The symbolic meaning contained in it makes a positive contribution to Islamic education for the younger generation in the region
\end{abstract}

\section{Abstrak}

Realitas budaya Indonesia yang beragam suku, tradisi yang berbeda, serta agama dan aliran yang berbau mitos merupakan dasar kehidupan sosial dan budaya. Bangsa Indonesia sejak dahulu percaya adanya kekuatan gaib yang mengatur alam ini. Hal ini terbukti dengan berbagai catatan sejarah mengenai berbagai macam upacara adat dan ritual. Kekuatan gaib tersebut ada yang dianggap menguntungkan dan merugikan. Untuk itu diyakini oleh beberapa kalangan bahwa manusia senantiasa perlu berupaya melembutkan hati pemilik kekuatan gaib dengan mengadakan upacara ritual, ziarah, sesaji, dan kaul, termasuk pementasan seni tertentu. Tradisi sedekah bumi (nyadran) di Kaplongan Lor, Karangampel, Indramayu merupakan salah satu kearifan lokal yang menggabungkan tradisi Hindu-Budha dan Islam. Makna simbolik yang terkandung di dalamnya memberikan kontribusi positif bagi pendidikan islam untuk generasi muda di wilayah tersebut. 


\section{PENDAHULUAN}

Manusia hidup tidak lepas dari ketergantungan dengan alam dan lingkungan sekitarnya. Untuk itu menjaga keselarasan hidup dibutuhkan keseimbangan dengan alam yang harus dijaga agar kehidupan masyarakat berjalan dengan lancar. Oleh karena itu muncul berbagai macam tradisi seperti selamatan yang diadakan secara individual seperti dalam peristiwa kelahiran, perkawinan, kematian dan peristiwa lainnya, maupun upacara adat yang dilaksanakan secara komunal di dalam masyarakat.

Manusia dapat melakukan sebuah tindakan sebagai wujud dari balas budi atau timbal balik yang positif pada lingkungan (alam) tempat manusia mencari penghidupan. Sebagaimana yang menjadi konsep budaya manusia yang terdiri dari gagasan, aktivitas, tindakan, dan juga wujud (sebagai benda). ${ }^{1}$ Manusia mengaktualisasikan rasa syukurnyamelalui gagasan yang kemudian diwujudkan dalam bentuk tindakan atau aktivitas. Hal ini yang menjadi dasar masyarakat Desa Kaplongan Lor Kec. Karangampel mengaktualisasikan rasa syukurnya atas semua yang diberikan atau dikaruniakan Allah SWT melalui sebuah budaya sebagai cipta karya masyarakat sendiri, yaitu (Nyadran) yang kemudian diartikan sebagai sebuah aktualisasi masyarakat untuk melaksanakan sedekah bumi.

Ichmi Yani Arinda R. dengan judul "Sedekah Bumi (Nyadran) Sebagai Konvensi Tradisi Jawa dan Islam Masyarakat Sraturejo Bojonegoro. Dalam penelitian ini dijelaskan bahwa sedekah bumi (nyadran) merupakan salah satu jenis tradisi masyarakat yang merupakan hasil konvensi atau kesepakatan bersama masyarakat untuk dipersatukannya budaya Jawa asli dengan nilai-nilai yang diajarkan dalam Islam. Dalam hal ini masyarakat yang menjadi objek penelitian tidak mempermasalahkan dilaksanakannya pelestarian tradisi sedekah bumi selama tidak menghilangkan nilainilai asli dari tujuan diadakannya sedekah bumi dan nilai-nilai yang diajarkan dalam Islam.

Jurnal yang ditulis oleh Slamet, dkk menjadi acuan sebagai tinjauan pustaka bagi penulis yaitu jurnal yang ditulis oleh Slamet dengan judul "Pemanfaatan Ruang Telaga Pada Tradisi Sedekah Bumi Desa Cerme Kidul, Kecamatan Cerme, Kabupaten Gresik". Penelitian ini, ditulis oleh tim Dinas Pekerjaan Umum Cipta Karya dan Tata

\footnotetext{
${ }^{1}$ Munandar Sulaeman, Ilmu Budaya Dasar, (Bandung: PT. Refika Aditama, 1998), h. 13.
} 
Ruang Provinsi Jawa Timur yakni Slamet yang berkolaborasi dengan Magister Arsitektur Lingkungan Binaan dari Universitas Brawijaya: Jenny Ernawati dan Agung Murti. Dalam penelitiannya, mereka menjelaskan bahwa tradisi sedekah bumi merupakan wujud syukur kepada Tuhan yang Maha Esa dan merupakan simbol kerukunan warga di Desa Cerme Kidul, Kabupaten Gresik dan juga merupakan wujud komunikasi antara manusia dengan alam. Dalam penelitiannya, Saeful dkk menggunakan teori behavior setting. Teori -teori yang digunakan menjelaskan terdapatnya hubungan timbal balik dan saling mempengaruhi satu sama lain. Metode yang digunakan yakni deskriptif kualitatif. Dari penelitian yang dilakukan oleh Saeful dkk menghasilkan kesimpulan bahwa tradisi sedekah bumi merupakan tradisi dari nenek moyang yang secara turun temurun dilakukan setiap tahun untuk mensyukuri nikmat yang telah diterima dan sebagai rasa syukur maka dilakukan tradisi sedekah bumi di bawah pohon Lom di Punden Telaga. ${ }^{2}$

Oki Setya Pamudi dalam Jurnal Pendidikan Bahasa dan Sastra UMC Purworejo. Oki memberi judul penelitiannya dengan Upaya Pelestarian Tradisi Baritan Dalam Upacara Adat Sedekah Bumi di Desa Kedungwringin kecamatan Sempor Kabupaten Kebumen. Penelitiannya menggunakan metode kualitatif dengan menggunakan pendekatan etnografi. Oki mengungkapkan bahwa tradisi Baritan atau sedekah bumi merupakan bentuk ungkapan rasa syukur kepada Allah SWT yang telah memberikan rezeki, keselamatan dan keamanan.

Selanjutnya, sebuah tulisan dengan judul Implementasi Tradisi Sedekah Bumi (Studi Fenomenologi di Kelurahan Banjarejo, Kecamatan Bojonegoro, Kabupaten Bojonegoro) oleh Isce Veralidiana, jurusan al-ahwal al-syakhsiyah Fakults Syari'ah UIN Maulana Malik Ibrohim Malang 2010. Skripsi ini menggunakan pendekatan fenomenologi yang lebih menekankan pada proses pelaksanaan ritual. Di dalam temuannya dijelaskan bahwa sedekah bumi dilaksanakan di makam Mbah buyut Pendem pada malam Jumat Kliwon dengan berbagai proses, seperti: mengadakan tahlilan pada malam sebelumnya, esok harinya warga membawa sesajen seperti nasi tumpeng, kemenyan, uang, dan bunga, dan ditutup dengan pertunjukan kesenian wayang kulit. Skripsi ini juga menjawab persoalan tentang tradisi sedekah bumi yang

\footnotetext{
${ }^{2}$ Slamet, dkk, "Pemanfaatan Ruang Tela ga Pada Tradisi Sedekah Bumi Desa Cerme Kidul, Kecamatan Cerme, Kabupaten Gresik," Jurnal RUAS, Volume 13 No 1, Juni2015, h. 47-55.
} 
dianggap melenceng dari ajaran Islam. Masyarakat menyetujui bahwa tradisi tersebut tidak membawa kemusyrikan apapun terhadap warga sekitar karena ini merupakan adat kebiasaan yang shahih, yang tidak terdapat unsur-unsur mistik maupun magic.

Skripsi Emmi Nur Afifah, "Korelasi konsep syukur dalam Budaya Jawa dan ajaran Islam (Studi Kasus Sedekah Bumi di Desa Tegalharjo Kecamatan Trangkil Kabupaten Pati)", Fakultas Ushuluddin Institut Agama Islam Negeri Walisongo Semarang 2015 ini bermaksud untuk mengungkap sinkretisme dalam sebuah tradisi dengan cara mendiskripsikan sistem kepercayaan masyarakat Desa Tegalharjo di dalam menjalankan ritual kebudayaan mereka tentang aspek syukur yang diwujudkan dalam formasi sedekah bumi. Di dalam skripsi ini penulisnya lebih menekankan rasa syukur dalam Islam, bukan hanya dalam bentuk kebudayaan saja. Sedekah Bumi merupakan bentuk implementasi masyarakat di dalam selametan untuk mensyukuri nikmat yang diberikan oleh Allah SWT. Sehingga dalam penelitian ini yang dimaksud oleh penulisnya adalah mempertemukan Konsep Syukur Islam dalam kebudayaan Jawa dengan Kearifan Lokal (local wisdom), secara umum kearifan lokal adalah (kearifan setempat) atau dapat dipahami sebagai gagasan-gagasan setempat (lokal) yang bersifat bijaksana, penuh kearifan, bernilai baik, yang tertanam dan diikuti oleh anggota masyarakatnya. ${ }^{3}$

Berdasarkan penelitian sebelumnya, penelitian ini yang memiliki dua tujuan, yaitu: 1) Untuk menggambarkan proses pelaksanaan tradisi sedekah bumi yang dilakukan oleh masyarakat Kecamataan Karangampel, Kabupaten Indramayu. 2) Untuk mengungkap makna simbolik dari prosesi sedekah bumi di Desa Kaplongan Lor, Kabupaten Indramayu dan korelasinya dengan pendidikan islam di wilayah tersebut.

\section{METODE PENELITIAN}

Metode yang digunakan dalam penelitian ini adalah metode deskriptif. Dengan demikian, penelitian ini dilakukan seobjektif mungkin terhadap hal-hal uang menjadi pusat pikiran dan mendukung objek penelitian. Sesuai dengan hakikat metode deskriptif, penelitian ini tidak berhenti pada pengumpulan data saja tetapi jauh dari itu. Data yang terkumpul akan diseleksi, dikelompokkan, dianalisis, diinterpretasi dan disimpulkan.

\footnotetext{
${ }^{3}$ Aan Ha sanah, dkk, Nilai-nilai Karakter Sunda (Yogyakarta: deepublish, 2016), h. 42.
} 
Jenis penelitian yang dipakai oleh penulis pada penelitian ini adalah deskriptif kualitatif. Jenis penelitian ini bertujuan untuk mendeskripsikan hal-hal yang terjadi pada masa lalu. Di dalamnya terdapat upaya untuk mendeskripsikan, mencatat, analisis dan menginterpretasi kondisi pada zaman dahulu terjadi. Dengan kata lain penelitian deskriptif kualitatif ini bertujuan untuk memperoleh informasi mengenai keadaan yang ada.

Pada hakikatnya penelitian deskriptif kualitatif adalah suatu metode dalam meneliti status kelompok manusia, suatu objek dengan tujuan membuat deskriptif, gambaran atau lukisan secara sistematis, faktual dan akurat mengenai fakta-fakta yang diselidiki.

Dalam penelitian ini, sumber data yang digunakan adalah data primer dan data sekunder. Data primer adalah data yang diperoleh atau dikumplukan langsung di lapangan oleh orang yang melakukan penelitian atau yang bersangkutan. Data primer didapatkan dari sumber Pustaka seperti; literatur, penelitian terdahulu, buku, dan lain sebagainya. Sedangkan data sekunder adalah data yang diperoleh atau dikumpulkan oleh seorang yang melakukan penelitian, data ini digunakan untuk mendukung informasi primer yang telah diperoleh yaitu bahan pustaka, literatur, buku dan lain sebagainya. Data sekunder di dapatkan dari sumber informan yaitu individu seperti hasil wawancara yang dilakukan oleh peneliti, antara lain; Catatan hasil wawancara, Hasil observasi lapangan. Data-data dari informan (Tetua Adat, Kyai, Ustadz dan lainlain).

Teknik analisis data yang dilakukan dalam penelitian ini untuk memberikan analisa dan interpretasi struktur, fungsi, dan nilai budaya yang terdapat dalam cerita tersebut, penulis menggunakan langkah-langkah sebagai berikut:

1) Menentukan aspek-aspek struktur, fungsi dan nilai budaya yang terdapat dalam tradisi lisan tersebut

2) Mendeskripsikan wujud struktur, fungsi dan nilai budaya yang terdapat dalam cerita rakyat tersebut.

3) Mengidentifikasi data yang ada hubungannya dengan aspek-aspek yang diteliti.

4) Mengelompokkan data tersebut ke dalam kategori struktur, fungsi dan nilai budaya. 
5) Menyeleksi data yang memiliki kemungkinan tidak cocok dengankelompok lain.

6) Menetapkan dan menyusun pernyataan-pernyataan berdasarkan data-data yang telah dikategorisasikan.

7) Memeriksa kembali apakah seluruh data yang telah dikategorisasikan sudah terdaftar atau belum.

8) Menginterpretasikan data yang telah dikategorikan sesuai dengan teori yang dipedomani.

9) Menarik kesimpulan

\section{KAJIAN TEORI}

Teori yang relevan sebagai landasan penelitian ini adalah interaksionisme simbolik. Istilah interaksionisme simbolik pertama kali dikenalkan oleh Herbert Blumer sekitar tahun 1939. Dalam lingkup sosiologi, ide ini sebenarnya sudah lebih dahulu dikemukakan oleh George Herbert Mead, tetapi kemudian dimodifikasi oleh Blumer guna mencapai tujuan tertentu. Teori ini memiliki ide yang baik, tetapi tidak terlalu dalam dan spesifik sebagaimana diajukan Mead. Dan ide dasar dalam perspektif ini lebih mengerucut pada pemikiran Herbert Mead yang merupakan guru dari Blumer. ${ }^{4}$ Karakteristik dasar teori ini adalah suatu hubungan yang terjadi secara alami antara manusia dalam masyarakat dan hubungan masyarakat dengan individu. Interaksi yang terjadi antar individu berkembang melalui simbol-simbol yang mereka ciptakan. Realitas sosial merupakan rangkaian peristiwa yang terjadi pada beberapa individu dalam masyarakat. Interaksi yang dilakukan antar individu itu berlangsung secara sadar. Interaksi simbolik juga berkaitan dengan gerak tubuh, antara lain suara atau vocal, gerakan fisik, ekspresi tubuh, yang semuanya itu mempunyai maksud dan disebut dengan "simbol". Interaksi yang terjadi antar individu berkembang melalui simbol-simbol yang mereka ciptakan. Realitas sosial merupakan rangkaian peristiwa yang terjadi pada beberapa individu dalam masyarakat. Interaksi yang dilakukan antar individu itu berlangsung secara sadar. Interaksi simbolik juga berkaitan dengan gerak tubuh, antara lain suara atau vocal, gerakan fisik, ekspresi tubuh, yang semuanya itu mempunyai maksud dan disebut dengan "simbol".

\footnotetext{
${ }^{4}$ George Ritzer dan Douglas J. Goodman, Teori Sosiologi, (Bantul: Kreasi Wa cana, 2014), h. 337.
} 
Perspektif ini lebih menekankan dan memfokuskan kajiannya terhadap urgensi simbol-simbol yang ada di setiap kehidupan manusia. Perspektif ini menyatakan bahwa sebagian besar tindakan manusia ialah direpresentasikan oleh simbol-simbol yang disepakati oleh masyarakat. Kunci pertama untuk mengetahui ide-ide dasar dari perspektif ini ialah dengan mengetahui definisi simbol itu sendiri. Perspektif ini mendefinisikan simbol sebagai sebuah objek sosial yang digunakan untuk merepresentasikan sesuatu yang disepakati untuk direpresentasikan. Dari pendefinisian tentang simbol memunculkan tiga premis dasar yang di ungkapkan oleh Herbert Blumer, yaitu:

1. Manusia bertindak terhadap sesuatu benda, kejadian atau fenomena tertentu berdasarkan makna yang dimilikinya.

2. Makna suatu benda, kejadian atau fenomena tersebut muncul dari interaksi sosial seseorang dengan y ang lain.

3. Makna suatu benda, kejadian atau fenomena tersebut disempurnakan dan dimodifikasi melalui proses interpretasi pada saat seseorang berhubungan dengan yang lain.

Pokok perhatian interaksionis simbolis adalah dampak makna dan simbol pada tindakan dan interaksi manusia. Dalam hal ini ada gunanya menggunakan gagasan Mead tentang perbedaan perilaku tertutup dengan perilaku terbuka. Perilaku tertutup adalah proses berfikir, yang melibatkan simbol dan makna. Perilaku terbuka tidak melibatkan perilaku tertutup (misalnya perilaku habitual atau respon tanpa berpikir terhadap stimulus eksternal). Namun kebanyakan tindakan manusia melibatkan kedua jenis perilaku tersebut. Perilaku tertutup menjadi pokok perhatian terpenting interaksionis simbolis, sementara itu perilaku terbuka menjadi pokok perhatian terpenting teoretisi pertukaran atau behavioris tradisional pada umumnya. ${ }^{5}$

Makna dan simbol memberi karakteristik khusus pada tindakan sosial (yang melibatkan aktor tunggal) dan interaksi sosial ( yang melibatkan dua aktor atau lebih dalam melakukan tindakan sosial secara timbal balik). Dengan kata lain ketika melakukan suatu tindakan orang juga mencoba memikirkan dampaknya pada aktor lain

\footnotetext{
${ }^{5}$ Sonhadji Sholeh, Sosiologi Dakwah, (Surabaya: IAIN Sunan Ampel Press, 2011), h. 19.
} 
yang terlibat. Meski sering kali terlibat dalam perilaku habitual tanpa berfikir, orang lain memiliki kapasitas untuk terlibat dalam tindakan sosial.

Dalam proses interaksi sosial, secara simbolis orang mengkomunikasikan makna kepada orang lain yang terlibat. Orang lain menafsirkan simbol-simbol tersebut dan mengarahkan respon tidakan berdasarkan penafsiran mereka. Dengan kata lain dalam interaksi sosial aktor terlibat dalam proses pengaruh-mempengaruhi.

\section{TRADISI SEDEKAH BUMI (NYADRAN) DI KAPLONGAN LOR, KARANGAMPEL, INDRAMAYU}

Ungkapan rasa syukur kepada sang pencipta dengan apa yang telah dianugerahkan kepada seluruh umat manusia, Allah telah menciptakan bumi dengan segala isinya dan Allah juga yang telah menjaganya, dengan berbagai perubahan musim yang telah mempengaruhi siklus bumi agar seimbang dan berbagai fenomena alam ini kadang manusia tidak dapat menyadari bahwa semua itu menunjukkan kekuasaan dan kebesaran Allah SWT. Oleh karena itu, salah satu bentuk rasa syukur kepada Allah SWT yang telah menciptakan bumi dengan segala isinya yaitu dengan melaksanakan ritual upacara sedekah bumi. ${ }^{6}$

Upacara sedekah bumi merupakan sebuah ritual yang biasanya dilakukan oleh masyarakat Jawa, sedekah bumi berarti menyedekahi bumi atau niat bersedekah untuk kesejateraan bumi. Bersedekah adalah hal yang sangat dianjurkan, selain sebagai bentuk dari ucapan syukur atas segala nikmat yang telah diberikan oleh Allah, bersedekah juga dapat menjauhkan diri dari sifat kikir dan dapat pula menjauhkan diri dari musibah. Melihat dari semua itu, sungguh sangat perlu untuk melaksanakan ritual sedekah bumi. Bumi yang hakikatnya sebagai tempat hidup dan bertahan hidup bagi semua makhluk yang ada di dalamnya, sudah selayaknya kita sebagai manusia yang sejatinya adalah khalifah ${ }^{7}$ atau pemimpin di muka bumi ikut menjaga dan mendo'akan agar keselamatan dan kesejahteraannya terjaga. Bila bumi sejahtera, tanah subur, tentram, tidak ada musibah, maka kehidupan dibumi pun akan terjaga dan manusia pun pada akhirnya yang memetik dan menikmati kesejahteraan itu.

\footnotetext{
${ }^{6}$ Joko Darmawan, Mengenal Budaya Nasional "Trah Raja-raja Mataram di Tanah Jawa (Yogyakarta: deepublish, 2017), h. 114.

${ }^{7}$ Munzir Hitami, Revolusi Sejarah Manusia (Yogyakarta:LKiS, 2009), h. 114.
} 
Indramayu adalah sebuah kabupaten di Provinsi Jawa Barat, Indonesia. Kabupaten ini berbatasan dengan Laut Jawa di Utara, Kabupaten Cirebon di Tenggara, Kabupaten Majalengka dan Kabupaten Sumedang, serta Kabupaten Subang di Barat. Indramayu terdiri dari 31 Kecamatan, yang dibagi lagi atas sejumlah 313 Desa dan Kelurahan. Pusat pemerintahan di Kecamatan Indramayu, yang berada di pesisir Laut Jawa. ${ }^{8}$

Desa Kaplongan Lor dulunya merupakan Desa Sukamanah Kecamatan Karangampel, sedangkan Desa Kaplongan itu sendiri berada di sebelah selatan Desa Sukamanah. kemudian pemekaran pada tahun 2004 yang akhirnya Desa Sukamanah menjadi Desa Kaplongan Lor, sedangkan Desa Kaplongan itu sendiri menjadi Desa Kaplongan Kidul. Jika Desa Kaplongan Lor Kecamatannya Karangampel sedangkan Desa Kaplongan Kidul Kecamatannya Kedokan Bunder.

Karangampel merupakan salah satu Kecamatan di Indramayu dengan memiliki 11 Desa, Desa Kaplongan Lor merupakan salah satu Desa di Kecamatan Karangampel dengan jumlah RT 11 dan 3 RW. Perbatasan Desa Kaplongan sebelah Barat dengan Desa Kaplongan Kidul, sedangkan bagian selatan berbatasan dengan Desa Tanjung Pura, Bagian Timur berbatasan dengan Desa Tanjung Sari, dan bagian Utara berbatasan dengan Desa Dukuh Jeruk. Kaplongan Lor sebuah entitas, bagian dari masyarakat Indramayu yang memiliki ciri khas tersendiri dengan masyarakat di wilayah lain. Wilayahnya yang berada pada daerah pesisir pantai utara Jawa Barat merupakan wilayah dengan keunikannya tersendiri dengan kabupaten-kabupaten di sekitarnya.

Indramayu yang berada pada wilayah Jawa Barat tentu seharusnya lebih kental akan dipengaruhi oleh Budaya Sunda, akan tetapi hal ini tidak terjadi pada kenyataanya. Kabupaten Indramayu tidak menggunakan Bahasa Sunda maupun Bahasa Jawa sepenuhnya, melainkan memakai bahasanya sendiri yakni yang disebut Bahasa Jawa Bagongan ${ }^{9}$ dan Basan. Bahasa bagongan biasanya dipakai untuk sehari-hari dengan orang sebaya, dan Bahasa Basan biasanya dipakai ketika berbicara dengan orang yang

\footnotetext{
${ }^{8}$ http://www.jabarprov.go.id/index.php/pages/id/1052

${ }^{9}$ Tati Nara wati, Wajah Tari Sundadari Masake masa (T.p.t.P4ST UPI, 2003), h. 390.
} 
lebih tua, maupun orang yang dihormati. ${ }^{10}$ Bahasa yang dipakai masyarakat Indramayu banyak menyerap Bahasa-bahasa Jawa serta sedikit Bahasa Sunda. ${ }^{11}$

Masyarakat Indramayu terdiri dari beberapa jenis masyarakat yang berbeda. ${ }^{12}$ Masyarakat petani, pedagang, nelayan, pertokoan, dan lainnya ialah yang masyarakat yang mewarnai kehidupan masyarakat Indramayu. Hal ini terjadi dikarenakan letak geografis dan keadaan sosial masyarakat.

Masyarakat Desa Kaplongan Lor sebagian masih peduli dengan pelaksanaan upacara-upacara adat, mereka masih meyakini akan manfaat dari pelaksanaan upacara adat yang sudah terselenggara sejak dahulu, sehingga mereka masih melestarikan upacara-upacara adat. Salah satu upacara adat yang masih dilestarikan adalah upacara adat sedekah bumi.

Perayaan sedekah bumi telah dilaksanakan secara turun-temurun dan tidak diketahui asal-usul serta awal mulai dilaksanakannya. Perayaan ini biasa dilaksanakan penduduk Desa Kaplongan Lor setiap tahun, adapun hari dan tanggal biasanya sesuai keputusan dari tetua masyarakat dan dilaksanakan selama 3 hari 3 malam. Adapun hiburan yang biasa menjadi pelengkap sedekah bumi yang ada di Desa Kaplongan Lor adalah hari pertama Wayang Kulit (malam hari), hari kedua Sandiwara (siang malam), kemudian hari yang ketiga pengajian umum(malam hari). ${ }^{13}$ Sebelumpelaksanaan acara tersebut, jauh sebelumnya pada malam hari tetua masyarakat mengadakan musyawarah dengan warga yang dianggap cukup ikut andil dalam acara ini supaya berjalan lancar.

Jauh sebelum ditetapkannya acara ritual sedekah bumi, warga masyarakat yang sudah ditunjuk oleh kepanitiaan sesuai dengan tanggung jawabnya untuk membuat kerangka bibit padi yang akan diarak dari tempat yang sudah ditentukan ke balai desa, lalu diantarkan ke pemakaman yang dianggap makam keramat. Adapun kerangka bibit padi itu adalah sebuah alat yang digunakan untuk mengangkut bibit padi secara simbolik. Kerangka tersebut dibuat dari batang bambu utnuk pikulannya sepanjang 1 1/2

\footnotetext{
${ }^{10}$ Sri Saa dah Soepono, F.X. Tito Adonis, Dampak Perkawinan Campuran Terhadap tatakrama Daerah Studi Kasus Pada Komuniti Perkotaan di Yogyakarta (Jakarta: Direktorat Jenderal Kebudayaan, T.p.t), h. 69-70.

${ }^{11}$ Sidik Permana, Antropologi Perdesaan dan Pembangunan Berkelanjutan (Yogyakarta: deepublish, 2016), h. 116.

${ }^{12}$ Halwany Michrob, Sejarah Perkembangan Arsitektur Kota Islam Banten: Suatu Kajian Arsitektural Kota Lama Banten menjelang Abad XVI Sampaidengan AbadXX (Banten: Yayasan Baluwati, 1993), h. 73.

${ }^{13}$ Wa wa ncara Priba di dengan Bapak Mukana, Kaplongan Lor 30 Oktober 2017.
} 
meter, kemudian sebagai pengait bibit padinya terbuat dari bambu utuh yang dibelah menjadi empat belahan akan tetapi belahan tersebut tidak sampai pangkalnya karena bagian pangkalnya dilubangin untuk dikaitkan dengan pikulan. Sedangkan ujung yang sudah terbelah dipasang nampan berukuran kecil sebagai tempat bibit padi yang dimaksud. Jelas ukuran bambu untuk pikulannya lebih kecil daripada bambu yang menjadi tempat padinya. Bambu yang dibelah untuk tempat bibit padi dibuat sebanyak 2 buah untuk ujung dan pangkal pikulan. ${ }^{14}$

Penganten-pengantenan yang dimaksud adalah kaum laki-laki dan perempuan yang dirias untuk simbol Dewi Wisnu dan Dewi Sri Pohaci. Dalam hal ini, dandanan yang digunakan tidak seperti penganten pada umumnya. Bagi penganten laki-laki menggunakan celana $1 / 4$ kaki dan baju panjang penuh lengan dengan warna hitam, sambil memikul cangkul di bahu kanan, sedangkan penganten perempuan menggunakan kebaya dengan ukuran lengan penuh, untuk bagian bawahnya menggunakan kain selendang batik, dan batasan penggunaannya 1/4 kaki. ${ }^{15}$ Tangan kanan sambil menggendong tempat yang terbuat dari anyaman bambu sebagai tempat beras (simbol makanan pokok). Baik penganten laki-laki maupun penganten perempuan semua menggunakan penutup kepala ketu (topi yang terbuat dari anyaman bambu dengan design kerucut).

Penataan nampan makanan dilakukan oleh para ibu-ibu, nampan yang pertama diisi dengan nasi tumpeng yang dihiasi dengan rebusan sayur-sayuran, kemudian nampan yang kedua diisi dengan panggangan ayam utuh (bakakak) yang dihiasi dengan lauk pauk lainnya seperti telor ayam, tempe bacam, tahu goreng. Kemudian nampan yang lainnya diisi dengan makanan ringan di antaranya: pipis (terbuat dari gilingan tepung beras yang ditengahnya dikasih sisiran pisang) ditaroh di pinggir nampan melingkar dua barisan, kemudian koci (terbuat dari gilingan tepung beras yang di tengahnya diberi parutan kelapa yang sudah diaduk dengan gula Jawa, berbentuk piramida) ditaroh di lingkaran dalam nampan dua baris. Sedangkan bagian tengah nampan diisi dengan kacang tanah yang sudah direbus. Adapun semua pinggiran nampan dikasih hiasan berupa lipatan daun pisang dengan design meruncing. ${ }^{16}$

\footnotetext{
${ }^{14}$ Wawa ncara Priba di dengan Bapak Mukana.

${ }^{15}$ Wa wa ncara Priba di den gan Bapak Ujro, Kaplongan Lor 29 Oktober 2019.

${ }^{16}$ Wa wa ncara Priba di dengan Ibu Saenah, Kaplongan Lor 29 Oktober 2019.
} 
Setelah semua persiapan sudah selesai, kemudian pada hari yang telah ditentukan tersebut, tetua adat dan warga masyarakat membawa semua barang-barang yang dijadikan ritual. Pelaksanaannya sekitar jam 13.00 siang diarak menuju balai desa Kaplongan Lor yang tentunya dido'akan oleh tetua masyarakat. Sesampainya di Balai Desa Kaplongan Lor bibit padi yang diarak tadi diserahkan kepada Kuwu Desa Kaplongan Lor dan dido'akan kembali oleh tetua masyarakat. Kemudian bibit padi tersebut dibawa kembali oleh masyarakat ke makam yang dianggap keramat oleh masyarakat setempat. Di makam tersebut semua barang bawaan masyarakat ditaroh di sekitar makam, salah satu warga masyarakat kemudian menaroh sesajen yaitu berupa bawang merah, cabe merah, dan daun salam yang ditusuk seperti sate.

Sesajen tersebut dipasang di empat penjuru makam. Kemudian tidak lupa untuk membakar kemenyan sebagai simbol wewangian, tidak lupa juga penaburan bungabunga di makam tersebut. kemudian dilakukan acara tahlilan dan do'a bersama yang dipimpin oleh tetua masyarakat. Setelah semuanya selesai, makanan yang dibawa oleh masyarakat dibagikan kembali kepada masyarakat dengan rata. ${ }^{17}$

Dalam acara penutupan malam hari diadakan pengajian sebagai penutup dari acara sedekah bumi, sedangkan besok siangnya dilakukan pembersihan lingkungan makam keramat dari sampah-sampah bekas acara hiburan selama tiga hari tiga malam, kemudian tahlil secara bersama-sama dengan masyarakat.

\section{ANALISIS MAKNA DAN SIMBOLISASI SEDEKAH BUMI (NYADRAN) DAN KORELASINYA DENGAN PENDIDIKAN ISLAM DI KAPLONGAN LOR, INDRAMAYU}

Masyarakat Desa Kaplongan Lor yang mayoritas bekerja sebagai petani telah lama menjalankan tradisi ini. Di dalam tradisi sedekah bumi, selain ada proses pembacaan doa, ada juga di setiap tahapan mempunyai simbol masing-masing yang bisa dilihat dari sesaji yang digunakan. Tradisi sedekah bumi ini tidak hanya dilakukan oleh perseorangan, namun dilakukan oleh orang-orang yang mempercayai makna dari tradisi ini sehingga tercipta suatu masyarakat pendukung tradisi sedekah bumi.

Simbol dari tradisi sedekah bumi terdiri dari alat pikulan bibit padi, bibit padi, sesajen, tumpeng, jajanan pasar, pertunjukkan wayang, dan pertunjukkan sandiwara (ketoprak).

\footnotetext{
${ }^{17}$ Wa wa ncara dengan Bapak Ujro, Ka plongan Lor 29 Oktober 2017.
} 
Alat pikulan bibit padi yang terbuat dari bambu ini mencerminkan sebagai alat yang terbuat dari hasil bumi untuk memikul hasil bumi juga, di sisi lain masyarakat petani harus saling bahu-membahu dalam mensyukuri nikmat Tuhan yang diberikan melalui bumi yaitu berupa padi, hal itu tercermin dalam bambu sebagai alat pikul. Seberapapun beratnya yang kita pikul diterima karena semua itu pemberian dari Tuhan Yang Maha Esa. Sedangkan media pengait sekaligus tempat bibit padi menjadi lambang masyarakat dalam menyambut panen dan dibebankan oleh seluruh lapisan masyarakat yang tercermin dari bambu yang dibelah menjadi empat.

Nampan yang dijadikan sebagai penyangga bibit padi dicerminkan sebagai lapisan masyarakat yang secara keseluruhan menghormati sekaligus menjunjung tinggi hasil panen. Rasa syukur kepada Tuhan Yang Maha Esa melalui hasil bumi yang didapatkan sangat berharga bagi masyarakat untuk keberlangsungan hidup. ${ }^{18}$

Padi bagi masyarakat Desa Kaplongan Lor ternyata bukan sembarang tanaman. Ia bukan hanya melebihi tanaman lain, tetapi mempunyai kesejajaran dengan manusia. Seperti halnya manusia, padi dipandang berasal dari alam dewata, langit, surga, atau Yang Maha Kuasa. Oleh karena itu, padi dan manusia mempunyai siklus hidup yang sama. Suatu kesamaan, kesejajaran, hubungan erat, dan relasi mistis yang justeru mengantarkan masyarakat kita menyatu dan simbiosis dengan alam. Beras, bagi mereka, tidak dilihat dari sudut ekonomi dan hanya untuk memenuhi kebutuhan kalori, vitamin, protein, dan sebagainya, melainkan merupakan buah perkawinan ilahi, tanaman firdaus, dan memiliki tenaga misterius yang menguatkan lahir-bathin. Sejumlah masyarakat menyatakan bahwa beras adalah makanan ilahi yang akan menimbulkan kekuatan, keberdayaan, dan mencegah kemalasan. Kulitnya tidak akan lapuk, tidak menjadi kotor, dan bulir-bulirnya melantunkan musik saat tertiup angin, tanpa harus tersentuh oleh manusia. ${ }^{19}$

Sesajen atau sajen dalam arti yang sebenarnya adalah menyajikan hasil bumi yang telah diolah manusia atasakemurahan Tuhan Yang Maha Esa sebagai penguasa kehidupan dan mengingatkan kita bahwa ini semua adalah milik Tuhan. Karena semuanya sudah ada ketika kita mulai diberi kehidupan, juga menggambarkan lingkungan biotik yang ada dan terkandung di bumi.

\footnotetext{
${ }^{18}$ Wawa ncara pribadi dengan Supaenah, Indramayu, 30 September 2017.

${ }^{19}$ Wa wa ncara dengan Bapak Sarijan Desa Kaplongan Lor, 29 September 2017.
} 
Tumpeng bagi orang Jawa merupakan ungkapan dari metu dalam kang lempeng atau hidup melalui jalan yang lurus. ${ }^{20}$ Selain itu, tumpeng ini sebagai penanda bahwa hasil panen yang diperoleh terbukti dapat dikonsumsi oleh masyarakat tanpa ada kekurangan apapun. Tumpeng juga dapat diartikan sebagai mengumpulkan masyarakat untuk berkumpul bersama. Tanpa tumpeng, tidak ada alat pemersatu masyarakat yang paling lekat.

Adapun jajanan yang terdapat dalam acara sedekah bumi ini melambangkan sebagai individu harus bisa menjadi bagian dari pada individu lainnya, artinya merasakan apa yang dirasakan oleh masyarakat lainnya. Dalam kehidupan kita tidak mungkin hidup dalam kesendirian, pasti membutuhkan orang lain sebagai teman dalam kehidupan di dunia. Masyarakat dikelilingi para tetuah desa maupun aparat pemerintahan sebagai pengayomnya.

Kemenyan dalam tradisi sedekah bumi untuk mengharumkan ruangan yang membawa ketenangan suasana adalah hal yang baik, sama ditinjau dari sudut adat maupun agama. Arang yang dinyalakan melambangkan elemen berupa api yang berguna bagi kehidupan manusia, dupa kemenyan yang artinya keharuman dan ketentraman juga sembah sujud dan penghantar doa kita kepada Tuhan juga menunjukkan eksistensi udara yang bergerak. Karena Rasulullah SAW menyukai wangi-wangian, baik berupa minyak wangi, bunga-bungaan ataupun pembakaran dupa pada pendupaan. ${ }^{21}$

Pelaksanaan upacara tradisi sedekah bumi yang diselenggarakan di Desa Kaplongan Lor merupakan usaha masyarakat setempat untuk menjaga keseimbangan alam, manusia menjaga hubungan dengan penguasa alam (hablum minallah) dan menjaga hubungan dengan sesama manusia (hablum minannas). Upacara religi atau agama, yang biasanya dilaksanakan oleh banyak masyarakat pemeluk religi atau agama yang bersangkutan bersama-sama mempunyai fungsi sosial untuk mengintensifkan solidaritas masyarakat. ${ }^{22}$ pada zaman dahulu, upacara sedekah bumi merupakan sarana pemujaan kepada nenek moyang dan sekaligus pemujaan kepada Dewi Sri (Dewa kesuburan menurut mitologi agama Hindu) agar masyarakat dijaga dari hal-hal yang

\footnotetext{
${ }^{20}$ M. Solikhin, Ritual dan Tradisi Islam Jawa,(Yogy akarta: IKAPI, 2010), h. 49-52

${ }^{21}$ Sja fi'I Hadzani, Seratus Masalah Agama (Kudus: Menara Kudus, 1982), h. 35.

${ }^{22}$ Koentjaraningrat, Sejarah TeoriAntropolgi (Jakarta: UI Press, 1981), h. 67.
} 
tidak diinginkan dan diberi kesuburan, sehingga akan tercipta masyarakat toto tentrem gemah ripah loh jinawi. Kini, hakikat upacara tradisi sedekah bumi adalah usaha bersama masyarakat memohon kepada Allah SWT agar selalu diberi keselamatan dan dijauhkan dari bencana serta selalu diberi kesejahteraan atau akan tercipta baldatun toyyibatun warobbun ghofur.

Tradisi sedekah bumi di KaplonganLor, Karangampel, Indramayu bukan hanya diisi dengan kegiatan adat yang berasal dari tradisi Hindu-Budha, tetapi juga ditambah tradisi Islam seperti tahlil, kenduri dan ziarah kubur, sehingga nuansa Islam pun muncul dalam tradisi ini. Dalam kaitannya dengan pendidikan Islam, acara sedekah bumi di Desa Kaplongan Lor, memiliki nilai-nilai yang dapat direkomendasikan sebagai nilainilai yang perlu diwariskan kepada generasi penerus, yaitu: satu, sikap religius masyarakat, yang tercermin sikap masyarakat yang selalu ingat kepada Allah SWT, sebab alam dan seluruh isinya adalah ciptaanNYA. Semakin manusia itu dekat kepada Allah SWT, maka Allah SWT akan menurunkan karunia dan rahmatNYA yang dapat berupa kesejahteraan dan kedamaian. Kedua, akan selalu ingat kepada jasa-jasa leluhur atau nenek moyang yang telah mendirikan Desa. Sikap ini perlu ditanamkan kepada generasi penerus, sehingga harapan kita, generasi penerus akan memiliki sikap mikul duwur mendem jero. Di samping itu, ada beberapa sikap yang telah diperlihatkan oleh masyarakat dalam melaksanakan acara tradisi sedekah bumi, dan sikap itu tertanam dalam hati para pemuda sebagai generasi penerus.

\section{PENUTUP}

Dari paparan di atas, tradisi sedekah bumi (nyadran) di daerah Kaplongan Lor, Karangampel, Indramayu merupakan kegiatan tahunan masyarakat setempat. Kegiatan ini merupakan ungkapan rasa syukur kepada Sang Pencipta atas nikmat-Nya yang melimpah ruah berupa hasil tanam yang banyak. Tradisi sedekah bumi ini, merupakan salah satu bentuk ritual tradisional masyarakat di Pulau Jawa yang sudah berlangsung secara turun-temurun dari nenek moyang orang Jawa terdahulu. Akan tetapi tradisi sedekah bumi mempunyai makna yang lebih dari itu, upacara tradisional sedekah bumi itu sudah menjadi salah satu bagian yang sudah menyatu dengan masyarakat yang tidak akan mampu untuk dipisahkan dari kultur (budaya) Jawa yang menyiratkan simbol 
Analisis Makna Simbolis Tradisi Sedekah Bumi (Nyadran) dan Pendidikan Islam di Kaplongan Lor, Indramayu

penjagaan terhadap kelestarian serta kearifan lokal, khas bagi masyarakat agraris maupun masyarakat nelayan khususnya yang ada di Pulau Jawa pada umumnya.

Simbolisasi tradisi sedekah bumi pun memiliki makna filosofis yang mecerminkan kehidupan yang baik. Meskipun awalnya berasal dari tradisi HinduBudha, pelaksanaan tradisi ini ini mengalami perubahan dengan memasukkan unsurunsur Islam di dalamnya. Nilai-nilai pendidikan Islam yang terkandung didalamnya sangat bagi bagi ditanamkan bagi generasi muda agar tidak tergerus arus moderenisasi global.

\section{DAFTAR PUSTAKA}

Anshory Ch, M. Nasruddin. Kearifan Lingkungan dalam Perspektif Budaya Jawa. Jakarta: YOI, 2007.

Budhiarno, Ari. "Simbol dan Makna Tradisi Penanaman Padi sebagai Kearifan Lokal Desa Yosomulyo," (Skripsi S1 Fakultas Ilmu Sosial Universitas Negeri Yogyakarta, 2013.

Chamin, Asykuri Ibn dan Baidhawy, Zakiyuddin. Purifikasi dan Reproduksi Budaya di Pantai Utara Jawa. T.p.t. Pusat Studi Budaya dan Perubahan Sosial, Universitas Muhammadiyah Surakarta, 2003.

Damami, Muhammad, Makna Agama Dalam Masyarakat Jawa .Yogyakarta: LESFI, 2002.

Darmawan, Joko. Mengenal Budaya Nasional "Trah Raja-raja Mataram di Tanah Jawa. Yogyakarta: deepublish, 2017.

Estinintyas, W., dkk, "Identifikasi dan Delineasi Wilayah Endemik Kekeringan untuk Pengelolaan Resiko Iklim di Kabupaten Indramayu.” Jurnal Meterologi dan Geofisika, Vol, 13, No. 1.

Geertz, Clifford. Agama Jawa: Abangan, Santri dan Priyayi dalam Masyarakat Jawa, ter. Aswab Mahasin. Jakarta: Pustaka Jaya, 2013.

George, Ritzer dan Douglas J. G., Teori Sosiologi, Penerjemah Alimandan. Bantul: Kreasi Wacana, 2008.

Ghazali, Adeng Muchtar, Antropologi Agama Upaya memahami Keragaman Kepercayaan, Keyakinan, dan Agama, Bandung: Alfabeta, 2011.

Giri MC, Wahyana. Sajen dan Ritual Orang Jawa. Yogyakarta: Narasi, 2009. 
Analisis Makna Simbolis Tradisi Sedekah Bumi (Nyadran) dan Pendidikan Islam di Kaplongan Lor, Indramayu

Giri, Wahyana. Sajen dan Ritual Orang Jawa. Yogyakarta, Penerbit Narasi. 2010.

Hadzani, Sjafi'i. Seratus Masalah Agama. Kudus: Menara Kudus, 1982.

Hasanah, Aan. dkk, Nilai-nilai Karakter Sunda. Yogyakarta: deepublish, 2012.

Hitami, Munzir. Revolusi Sejarah Manusia. Yogyakarta: LKiS, 2009.

Irianto, Agus Maladi. Tayub, antara Ritualitas dan Sensualitas: Erotika Petani Jawa Memuja Dewi. Bandung:Laboratorium Seni dan Kebudayaan Lengkong Cilik, 2005.

Iswari, Rini. Pengkajian dan Penulisan Upacara Tradisional di Kabuapten Cilacap. Semarang: Dinas Pendidikan dan Kebudayaan, 2006.

Kahmad, Dadang. Sosiologi Agama. Bandung: Pustaka Setia, 2011.

Koentjaraningrat, Sejarah Teori Antropolgi. Jakarta: UI Press, 1981.

Merlina, Nina. "Budaya Spiritual pada Masyarakat Indramayu” Patanjala, Vol. 3, No. 3,2011 .

Michrob, Halwany. Sejarah Perkembangan Arsitektur Kota Islam Banten: Suatu Kajian Arsitektural Kota Lama Banten menjelang Abad XVI Sampai dengan Abad XX. Banten: Yayasan Baluwati, 1993.

Narawati, Tati. Wajah Tari Sunda dari Masa ke masa. T.p.t. P4ST UPI, 2003.

Nazir, Moh, Metode Penelitian, Jakarta: PT. Ghalia Indonesia, 2003.

Negoro, Suryo S. Upacara Tradisional dan Ritual Jawa. Surakarta: Buana Jawa, 2001.

Permana, Sidik. Antropologi Perdesaan dan Pembangunan Berkelanjutan. Yogyakarta: deepublish, 2016.

Ratna N, Dwi, "Perubahan dan Pergeseran Simbol Di Kota Yogyakarta1945-1949," Jantra, vol II, no. 3, Juni 2007.

Sholikhin, Muhammad. Ritual dan Tradisi Islam Jawa. Yogyakarta, Narasi. 2010. 